\title{
Characterisation of a novel Mannheimia sp from Australian feedlot cattle
}

\author{
PJ BLACKALL ${ }^{a}, \varnothing$ ANGEN $^{b}, N^{\prime}$ FEGAN ${ }^{a}$, LL BLACKALL $^{c}$, R MUTTERS $^{d}$ and M BISGAARD ${ }^{e}$
}

Objective To characterise eight isolates of a Gram-negative organism obtained from the upper respiratory tract of cattle showing evidence of mild upper respiratory tract disease.

Design The isolates were compared with the five recognised species within the genus Mannheimia - $M$ haemolytica, $M$ glucosida, $M$ granulomatis, $M$ ruminalis and $M$ varigena - using a range of phenotypic and genotypic methods.

Results Phenotypic characterisation indicated that the isolates belonged to the trehalose-negative [Pasteurella] haemolytica complex. This complex has recently been reorganised into five species within the new genus Mannheimia. Ribotyping performed using HindIII and a computerised analysis system indicated that the eight Australian isolates formed a distinct cluster that was related to, but different from, the five recognised species of Mannheimia. The 16S rRNA sequence of one isolate (BNO311) was determined and a phylogenetic analysis performed. Isolate BNO311 was distinct from the five named Mannheimia spp but did join a larger cluster consisting of rRNA cluster IV ( $M$ varigena) and the unnamed rRNA cluster $\mathrm{V}$ of Mannheimia. DNA:DNA hybridisation between isolate BNO311 and $M$ haemolytica NCTC $9380^{\top}$, M granulomatis P411 and Actinobacillus ligniersii NCTC $4189^{\top}$ all suggested similarities of approximately $30 \%$.

Conclusions These phenotypic and genotypic characterisation studies suggest that the eight Australian isolates represent a new species of Mannheimia. Until further characterisation studies are performed, we are unwilling to propose a name for this taxon, preferring to refer to this possible new species as Bisgaard taxon 39 of cluster $\mathrm{V}$ of Mannheimia. Aust Vet J 2001;79:634-639

Key Words: Mannheimia haemolytica, Mannheimia glucosida, Mannheimia granulomatis, Mannheimia ruminalis, Mannheimia varigena, characterisation, Pasteurella

[Pasteurella] haemolytica (the brackets indicate that this taxon was excluded from the genus Pasteurella sensu stricto in 1985¹) has long been associated with respiratory disease in cattle. ${ }^{2}$ $\mathrm{H}$ istorically, there have been two biotypes of [P] haemolytica recognised - biotype A consisting of isolates that ferment Larabinose and biotype $T$ consisting of isolates that ferment trehalose. 3,4 A third biotype was proposed for those [P] haemolytica isolates that did not fit this $A / T$ pattern. ${ }^{5}$

\footnotetext{
animal Research Institute, Queensland Department of Primary Industries, Yeerongpilly, Queensland 4105 (E-mail blackap@dpi.qld.gov.au)

bDepartment of Microbiology, Danish Veterinary Laboratory, DK-1790 Copenhagen V, Denmark

CDepartment of Microbiology and Parasitology, The University of Queensland, Brisbane, Queensland 4067

d Institut für Medizinische Mikrobiologie, Klinikum der Philipps-Universtät, D35037 Marburg, Germany

e Department of Veterinary Microbiology, The Royal Veterinary and Agricultural University, DK-1870 Frederiksberg C, Denmark
}

A series of studies suggested that the trehalose-positive isolates within $[P]$ haemolytica represented a distinct species. ${ }^{6-8}$ D espite the general acceptance that trehalose-positive $[P]$ haemolytica are not closely affiliated with the genus Pasteurella sensu stricto, these organisms were classified as [P] trehalosi. ${ }^{9}$ In terms of serovars, $[P]$ trehalosi contains [P] haemolytica serovars 3, 4, 10 and $15 .{ }^{9}$

The trehalose-negative [P] haemolytica complex has recently been the subject of an extensive polyphasic study that has used a range of genotypic and phenotypic methods. ${ }^{10-12}$ This has resulted in the proposal of a new genus, $M$ annheimia, for the trehalose-negative isolates of [P] haemolytica. ${ }^{13}$ In the creation of the genus $M$ annheimia, a total of five new species were recognised - M haemolytica, $M$ glucosida, M granulomatis, $M$ ruminalis and $M$ varigena. ${ }^{13}$ The bulk of what was once regarded as trehalose-negative $[P]$ haemolytica is now recognised as $M$ haemolytica, specifically $[P]$ haemolytica serovars $1,2,5,6,7,8,9$, $12,13,14$ and 16 . The isolates once recognised as [P] haemolytica serovar 11 have been reclassified as M glucosida. ${ }^{13}$ Serotyping, however, does not result in a clear, species-specific diagnosis. ${ }^{14}$

In the current study, we describe the isolation and characterisation of a collection of $\mathrm{M}$ annheimia-like organisms from Australian feedlot cattle.

\section{M aterials and methods}

I solates

All eight Australian isolates examined in this study were isolated from nasal swabs obtained from cattle in a feedlot. The nasal swabs were cultured by inoculation onto $5 \%$ sheep blood agar. Three sequential single colony picks were performed to ensure each isolate was pure. The organisms were then stored by freeze-drying. A fresh ampoule was opened each time for characterisation work. The reference strains used in this study (listed in Table 1) are all held in the collection of D epartment of Veterinary M icrobiology, The Royal Veterinary and Agricultural University, Copenhagen, D enmark.

Phenotypic characterisation

A full phenotypic characterisation was performed using methods previously described. ${ }^{15}$

\section{Ribotyping}

Subcultures from stocks kept at $-80^{\circ} \mathrm{C}$ were made on blood agar plates (0 xoid Blood Agar Base III supplemented with $5 \%$ bovine blood), which were incubated for $24 \mathrm{~h}$ at $37^{\circ} \mathrm{C}$. Single colonies were transferred to Luria-Bertani broth ${ }^{16}$ supplemented with $5 \%$ bovine serum. The cultures were grown overnight with shaking at $37^{\circ} \mathrm{C}$. Isolation of total DNA, restriction digestion using the enzyme $\mathrm{H}$ indllI (Boehringer $\mathrm{GmbH}$, M annheim, Germany), separation on $0.8 \%$ agarose gels, DNA blotting, and hybridization at $56^{\circ} \mathrm{C}$ with a digoxigenin-labelled probe (Boehringer) complementary to $16 \mathrm{~S}$ 
Table 1. Properties of Australian isolates of Mannheimia sp separating this taxon from the type or reference strains of the recognised Mannheimia species. ${ }^{a}$

\begin{tabular}{|c|c|c|c|c|c|c|c|c|}
\hline & $\begin{array}{l}\text { Australian } \\
\text { strains } \\
\text { (Taxon 39) }\end{array}$ & $\begin{array}{c}\text { M haemolytica } \\
\text { NCTC } 9380^{\top}\end{array}$ & $\begin{array}{c}\text { M glucosida } \\
\text { CCUG } 38457^{\top}\end{array}$ & $\begin{array}{c}\text { M ruminalis } \\
\text { CCUG } 38470^{\top}\end{array}$ & $\begin{array}{l}\text { M granulomatis } \\
\text { ATCC } 49244^{\top}\end{array}$ & $\begin{array}{c}\text { M varigena } \\
\text { CCUG } 38462^{\top}\end{array}$ & $\begin{array}{c}\text { Mannheimia sp } \\
\quad \text { R } 19.2\end{array}$ & $\begin{array}{c}\text { Mannheimia sp } \\
\text { HPA } 121\end{array}$ \\
\hline Oxidase & - & + & + & + & W & + & + & + \\
\hline$\beta$-haemolysis & W & W & W & - & - & W & W & - \\
\hline ODC & - & - & + & - & - & + & - & - \\
\hline Indole & - & - & - & - & - & - & $(+)$ & + \\
\hline \multicolumn{9}{|l|}{ Acid from } \\
\hline $\mathrm{D}(-)$ arabinose & - & - & W & $(+)$ & W & W & - & - \\
\hline $\mathrm{L}(+)$ arabinose & - & - & - & - & - & + & + & + \\
\hline Dextrin & $+/(+)$ & + & + & - & $(+)$ & W & $(+)$ & $(+)$ \\
\hline L(-) fucos & - & + & + & - & W & + & - & W \\
\hline $\mathrm{D}(+)$ galactose & - & + & + & + & $(+)$ & + & + & + \\
\hline Glycerol & - & - & $(+)$ & - & $(+)$ & $(+)$ & $(+)$ & - \\
\hline Meso-inositol & - & W & $(+)$ & - & W & $(+)$ & + & $(+)$ \\
\hline Maltose & $+/(+)$ & + & + & - & $(+)$ & + & + & + \\
\hline Raffinose & D & $(+)$ & $(+)$ & - & - & $(+)$ & $(+)$ & $(+)$ \\
\hline $\mathrm{L}(+)$ rhamnose & - & - & - & - & - & + & - & - \\
\hline D(-) sorbitol & $\mathrm{D}$ & + & + & - & + & - & - & + \\
\hline $\mathrm{D}(+)$ xylose & - & + & + & - & - & + & + & + \\
\hline ONPG & - & - & + & + & + & + & + & + \\
\hline Glycosides $^{\mathrm{b}}$ & - & - & + & - & + & - & - & - \\
\hline$\alpha$-fucosidase & $\mathrm{D}$ & + & + & - & - & + & - & W \\
\hline$\beta$-glucuronidase & - & + & - & - & + & - & - & - \\
\hline$\beta$-xylosidase & - & - & + & - & - & - & + & - \\
\hline No. of differences & & 5 & 10 & 6 & 5 & 10 & 9 & 7 \\
\hline
\end{tabular}

a ODC = ornithine decarboxylase; $\mathrm{W}=$ weak positive $;+=$ positive within $1-2$ days, $(+)=$ delayed positive within 14 days; $\mathrm{D}=$ variable reaction, $-=$ negative after 14 days

b Glycosides are aesculin, amygdalin, arbutin, cellobiose, gentiobiose and salicin

and $23 \mathrm{~S}$ rRN A of Escherichia coli (Sigma) were performed as previously described. ${ }^{12}$

\section{Analysis of ribotype patterns}

The ribotype patterns were analysed using GelC ompar (Applied M aths BVAB). A mixture of digoxigenin labelled molecular markers II and III (Boehringer) was used in every 5th lane for standardisation of gels. The band positions were analysed using fine optimisation and $0.8 \%$ position tolerance. The similarity between individual strains and the type strains of the five $M$ annheimia species and the three strains representing the unnamed rRN A cluster $V$ of $M$ annheimia ${ }^{13}$ was estimated using the Dice coefficient as a measure of similarity. Cluster analysis based on the similarity matrix obtained was done using the Unweighted Pair Group M ethod of Arithmetic Averages (UPGMA).

\section{Amplification and sequencing of $16 \mathrm{~S}$ rRN A}

The small subunit (16S) rRN A gene was amplified directly from cell biomass using $27 \mathrm{f}$ and $1525 \mathrm{r}$ primers. ${ }^{17} \mathrm{~A} 1-\mu \mathrm{L}$ sterile disposable loop was used to lift a small amount of colony material from the surface of an overnight blood agar plate into $200 \mu \mathrm{L}$ sterile phosphate buffered saline in a 0.6-mL tube. After vortexing, the suspension was heated on the thermal cycler at $98^{\circ} \mathrm{C}$ for $15 \mathrm{~min}$. The cell debris was pelleted by centrifuging at maximum speed in a benchtop microfuge for 5 min and $1 \mu \mathrm{L}$ of the supernatant was used as template. The 50 - $\mu \mathrm{L}$ reaction mixture contained $1 \mathrm{mM} \mathrm{M} \mathrm{gCl}, 50 \mathrm{mM} \mathrm{KCl}, 10 \mathrm{mM}$ Tris $\mathrm{HCl}$ (pH 8.3), $100 \mu \mathrm{g} / \mathrm{mL}$ gelatin, $200 \mathrm{mM}$ each dN TP (dATP,
dCTP, dGTP, dTTP), $0.4 \mu \mathrm{M}$ of each primer $27 \mathrm{f}$ and $1525 \mathrm{r}, 1$ $\mu \mathrm{L}$ of template and 0.8 units Taq D N A polymerase (Boehringer $M$ annheim). The PCR was performed using a $H$ ybaid $O$ mniG ene Thermal Cycler ( $\mathrm{H}$ ybaid, M iddlesex, UK). An initial heating step at $98^{\circ} \mathrm{C}$ for 2.5 min was performed prior to the addition of the Taq D N A polymerase. A $50-\mu \mathrm{L}$ mineral oil overlay was then added. The following cycling parameters were used: denaturing at $93^{\circ} \mathrm{C}$ for $1 \mathrm{~min}$, annealing at $52^{\circ} \mathrm{C}$ for $45 \mathrm{~s}$ and extension at $72^{\circ} \mathrm{C}$ for $2 \mathrm{~min}$, these three steps being repeated for 30 cycles. This was followed by a final cycle with an extension step of $10 \mathrm{~min}$. The PCR product for sequencing was purified using the QIAquick PCR Purification kit (QIAGEN $\mathrm{GmbH}, \mathrm{H}$ ilden, G ermany). D N A sequencing was performed using the $A B I$ Prism $^{T M}$ D ye Terminator Cycle Sequencing Ready Reaction Kit with Amplitaq ${ }^{\circledR}$ D N A Polymerase FS and a model 373A DNA sequencing system (PE Applied Biosystems Inc., Foster City, CA, USA). All procedures were performed according to the manufacturer's protocols. Both strands of the $16 \mathrm{~S}$ rD N A were sequenced using the primers 27f, 342r, 357f, 519r, 530f, 787r, 803f, 1100r, 1114f, 1241f, 1392r and $1492 r^{18}$ The sequence determined for BN 0311 was deposited in EM BL under accession number AF216870.

\section{Phylogenetic analysis of sequence data}

The sequence of strain BN 0311 was aligned with selected sequences from GenBank and analysed using the $A R B$ program. ${ }^{19} \mathrm{M}$ aximum likelihood analysis was performed using fastD N Aml. ${ }^{20}$ Bootstrapping (2000 resamplings) was performed according to previously described methods. ${ }^{21}$ 


\section{N A:D N A hybridisation}

Cells were grown under shaking at $37^{\circ} \mathrm{C}$ in Tryptic Soy Broth (D ifco) supplemented with $0.4 \%$ filter sterilized yeast extract ( 0 xoid) and $0.01 \mathrm{M} \mathrm{NaH} \mathrm{CO}_{3}$. The cells were harvested in the early-stationary phase of growth, examined microscopically for purity, washed in 1 X SSC $(0.15 \mathrm{M} \mathrm{N} \mathrm{aCl}, 0.015 \mathrm{M}$ trisodium citrate) and resuspended in 1 X SSC containing $0.01 \mathrm{M}$ EDTA. $\mathrm{H}$ igh-molecular-mass DNA was isolated as previously described.13 Initial renaturation rates of homologous or heterologous solutions of D N A were determined by a previously described method ${ }^{22}$ using a model 250 spectrophotometer (Gilford Instruments). A D N A concentration of $80 \mu \mathrm{g} / \mathrm{mL}$, a salt milieu containing $2 \times \mathrm{SSC}$ and a reassociation temperature of $68^{\circ} \mathrm{C}$ were used. The reassociation temperature was calculated as previously proposed. ${ }^{23}$ The DNA binding values (D\%) were calculated according to a published formula. ${ }^{22}$ Each experiment was repeated at least three times.

\section{Results}

\section{I solation}

Each isolate was obtained from a different animal within the one herd, with all animals suffering from mild respiratory disease. Although no other bacterial pathogen was isolated, all eight isolates were obtained as part of a mixed flora. The isolates were recognised due to the weak zone of haemolysis surrounding the colonies.

\section{Phenotypic characterisation}

All eight field isolates were Gram-negative, non-motile rods that fermented glucose without the production of gas, did not produce urease or indole and lacked oxidase activity. The isolates all showed weak haemolysis of both bovine and ovine blood cells. The isolates had no requirement for $X$ - or $V$-factors in vitro, were unable to utilise citrate, mucate or mal onate, did not produce $\mathrm{H}_{2} \mathrm{~S}$, did not produce any pigment, could not grow in potassium cyanide and were negative in the methyl red and Vogues-Proskaur tests. All the isolates could reduce nitrate without the formation of gas but lacked the ability to hydrolyse arginine and decarboxylate lysine or ornithine and could not hydrolyse gelatin, Tween 20 or Tween 80 . N one of the isolates could grow on $\mathrm{M}$ acC onkey agar or deaminate phenylalanine but all showed catalase and phosphatase activity. All the isolates were negative for $\alpha$-galactosidase, $\alpha$-glucosidase, $\alpha$-mannosidase, $\beta$ galactosidase, $\beta$-glucosidase, $\beta$-glucuronidase and $\beta$-xylosidase activity but all were positive for alanine aminopeptidase activity. $\mathrm{N}$ one of the isolates produced acid from adonitol, aesculin, amygdalin, D(-) arabinose, $L(+)$ arabinose, $D(+)$ arabitol, arbutin, cellobiose, dulcitol, meso-erythritol, $D(+)$ fucose, $L(-)$ fucose, $D(+)$ galactose, gentiobiose, $\beta-\mathrm{N}-\mathrm{CH}_{3}$-glucosamide, glycerol, $D(+)$ glycogen, meso-inositol, inulin, lactose, $D(+)$ mannose, $D(t)$ melibiose, $D(+)$ melezitose, $L(+)$ rhamnose, salicin, $L(-)$ sorbose, trehalose, $D(+)$ turanose, xylitol, $D(+)$ xylose or $\mathrm{L}(-)$ xylose. All the isolates produced acid from dextrin, D (-) fructose, D (+) glucose, D (-) mannitol, maltose, D (-) ribose and sucrose. The isolates differed in the ability to produce acid from raffinose and $D(-)$ sorbitol with only two and three isolates, respectively, being positive for these properties. Five of the eight isolates were positive for $\alpha$-fucosidase activity.

The above properties indicated that the isolates were in the trehalose-negative [P] haemolytica complex. However, comparison of the properties of the field isolates with the type or reference strains of the recognised $M$ annheimia species (see Table
1), showed that the Australian field isolates were clearly distinct. The nearest matches in phenotypic properties were $M$ haemolytica and $M$ granulomatis and even then, there were five differences with both species.

\section{Ribotyping}

The eight Australian field isolates all yielded unique but similar ribotype patterns. The patterns contained between 14 to 23 well-resolved bands. Estimates of the degree of similarity between the field isolates and the type or reference strains for the recognised $M$ annheimia spp are presented in the phenogram shown in Figure 1. Seven of the Australian field isolates formed a cluster at a similarity of $78 \%$. The eighth Australian isolate joined this cluster at a similarity of $72 \%$. T his Australian cluster did not join with the rest of the $M$ annheimia strains until a similarity of less than $30 \%$ was reached. These clustering results indicate that the Australian isolates represent a coherent cluster, which is clearly distinguishable from the recognised $M$ annheimia species.

\section{Phylogenetic analysis}

Phylogenetic analysis of the 16S rRNA gene sequence of strain BN 0311 showed that the isolate could not be reliably assigned to any of the five currently recognised $16 \mathrm{~S}$ rRN A clusters. ${ }^{13} \mathrm{~A}$ phylogenetic tree showing the relationship of strain BNO 311 in relation to the genus M annheimia and selected reference strains in the family Pasteurellaceae is shown in Figure 2. The bootstrapping analysis showed that strain BN 0311 is not reliably linked with the other members of the genus $M$ annheimia until rRNA clusters IV ( $M$ varigena) and V (a collection of un-named Mannheimia isolates) merge. As expected, the bootstrapping analysis supported the other previously recognised clusters - I M haemolytica/M glucosida, II - M ruminalis, III - M granulomatisand IV - M varigena.

\section{DNA:DNA hybridisation}

The D N A:D N A hybridisation work with strain BN 0311 and selected type/reference strains resulted in $D N A$ relatedness values of $33 \% \pm 7 \%$ (M haemolytica N CTC $9380^{\top}$ ), $30 \% \pm 3 \%$ (M granulomatisP 411 ) and $28 \% \pm 7 \%$ (Actinobacilluslignieresi N CT ( $4189^{\top}$ ).

\section{Discussion}

The phenotypic characterisation of the eight Australian isolates indicated that they were members of the trehalosenegative [P] haemolytica complex, which has recently been extensively re-organised and placed within the new genus $\mathrm{M}$ annheimia. ${ }^{13} \mathrm{H}$ owever, the isolates did not match any of the five recognised species nor representatives of the currently un-named taxa within the genus M annheimia (see Table 1).

Ribotyping was originally proposed as a taxonomic tool by G rimont and G rimont. ${ }^{24}$ It has been suggested that the value of ribotyping for the calculation of taxonomic distances between strains is questionable. ${ }^{25}$ The caution on the use of ribotyping arises from the fact that ribotype fragments of similar size may not represent homologous D N A sequences and that the fragments are not independent as removal of a single restriction site may result in a difference of three bands. ${ }^{13} \mathrm{~N}$ evertheless, ribotyping has proven a useful taxonomic tool in diverse bacterial groups including the family Pasteurellaceae. Ribotype clusters have been shown to be a useful way of separating Actinobacillus equuli isolates and related species. ${ }^{26}$ Ribotyping 

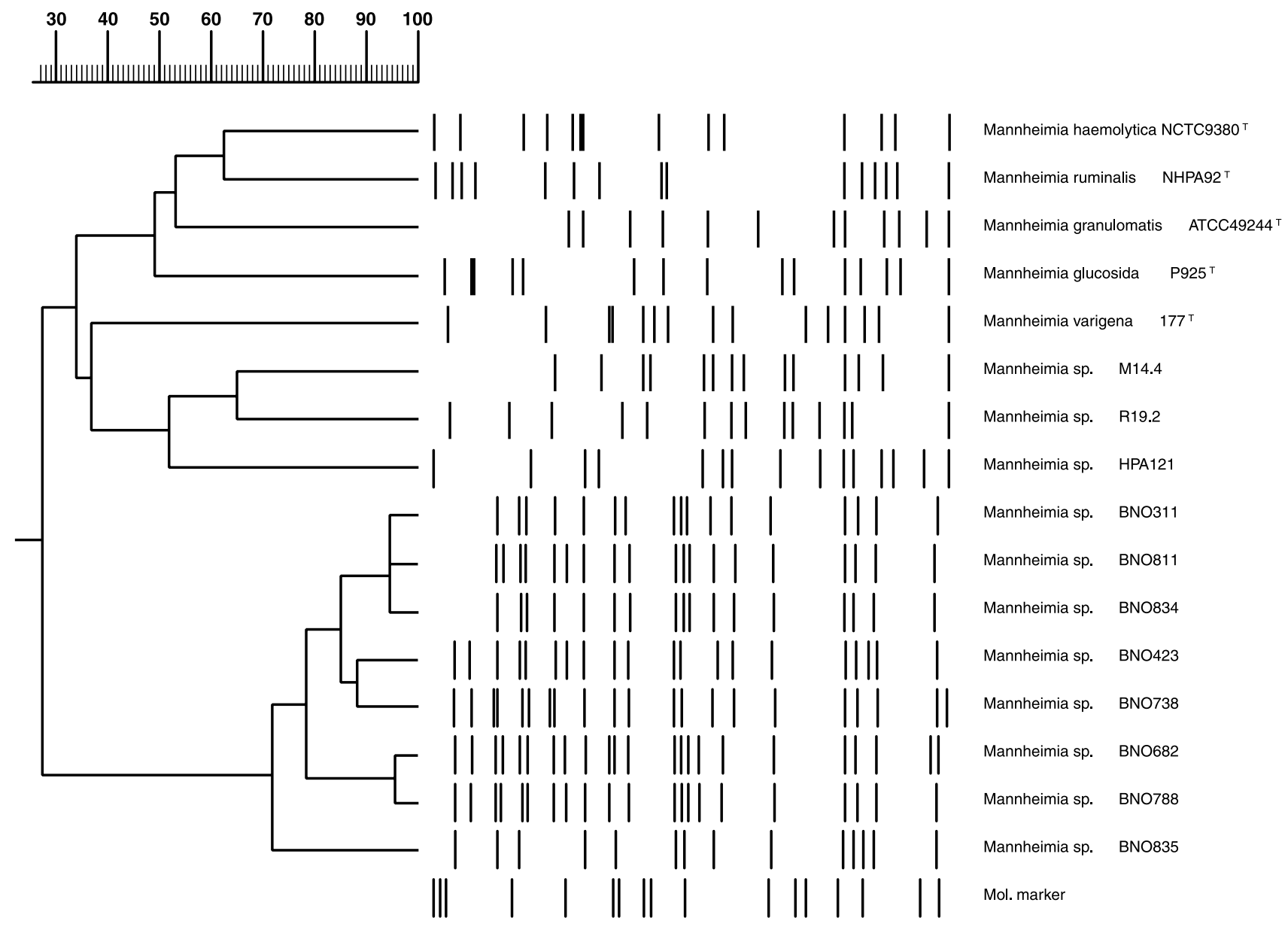

Figure 1. Analysis of ribotype patterns of eight Australian isolates and selected type and reference strains from the genus Mannheimia based on HindIII digestion, Dice coefficient of similarity and clustering by UPGMA. Fragment sizes of molecular weight marker (bp): 27491, 23130, 21226, 9416, 6557, 5148, 4973, 4361, 4268, 3530, 2322, 2027, 1904, 1584, 1357, 947 and 831.

clusters of both avian Pasteurella multocida and trehalose negative $[P]$ haemolytica have been shown to correlate with multi-locus enzyme electrophoresis (M LEE) clusters. ${ }^{12,27}$ As M LEE clusters have been shown to correlate with measures of overall DNA homology as revealed by DNA:DNA hybridisation in a range of bacteria, ${ }^{28-31}$ this is further evidence of the applicability of ribotyping.

Ribotyping clearly showed that the eight Australian isolates were a distinct cluster that did not join the recognised $M$ annheimia spp until a very low-level similarity of less than $30 \%$ (see Figure 1). Furthermore, the ribotyping results indicated that the Australian isolates were a tight cluster with all eight isolates sharing at least $72 \%$ similarity. The figure of $70 \%$ similarity for ribotype clusters within the trehalose-negative [P] haemolytica complex has been shown previously to result in clusters that match with the new species within the genus $\mathrm{M}$ annheimia. ${ }^{13} \mathrm{H}$ ence, the results of our ribotyping work suggest that the eight Australian isolates represent a new species within the genus M annheimia.

Analysis of the 16S rRNA sequence of Australian isolate BN 0311 (see Figure 2) established that the isolate could not be reliably linked with any of the five currently recognised rRN A clusters described by Angen et al. ${ }^{13}$ I solate BN 0311 is reliably linked with the larger cluster formed by rR N A Clusters IV (that is, $M$ varigena) and $V$ (a collection of un-named isolates). Bovine isolates of $M$ varigena have been associated with disease conditions such as pneumonia, mastitis and septicaemia as well as being isolated from non-sterile sites such as the rumen, oral cavity and intestine. ${ }^{13} \mathrm{~T}$ he $\mathrm{Cluster} V$ isolates have been obtained from bovine rumen (H PA121, R 19.2) or a bovine abortion (PH 704). ${ }^{13}$ The distinctive nature of isolate BN 0311 was further confirmed by the D N A:D N A hybridisation results in which we found no relatedness value of greater than 33\% with representatives of $M$ haemolytica, $M$ granulomatis and A lignieresii.

Although the isolates were all obtained from cattle with respiratory disease, this is not convincing evidence that the Australian isolates are linked to bovine respiratory disease. The isolates were obtained in mixed growth from the upper respiratory tract. It is possible that the isolates may be a component of the normal microbiota and that similar organisms can be found in the upper respiratory tract of healthy cattle. We hope that this description of the phenotypic and genotypic properties of the Australian isolates will result in other laboratories developing the capacity to identify these organisms. $W$ ith a range of laboratories capable of recognising these 


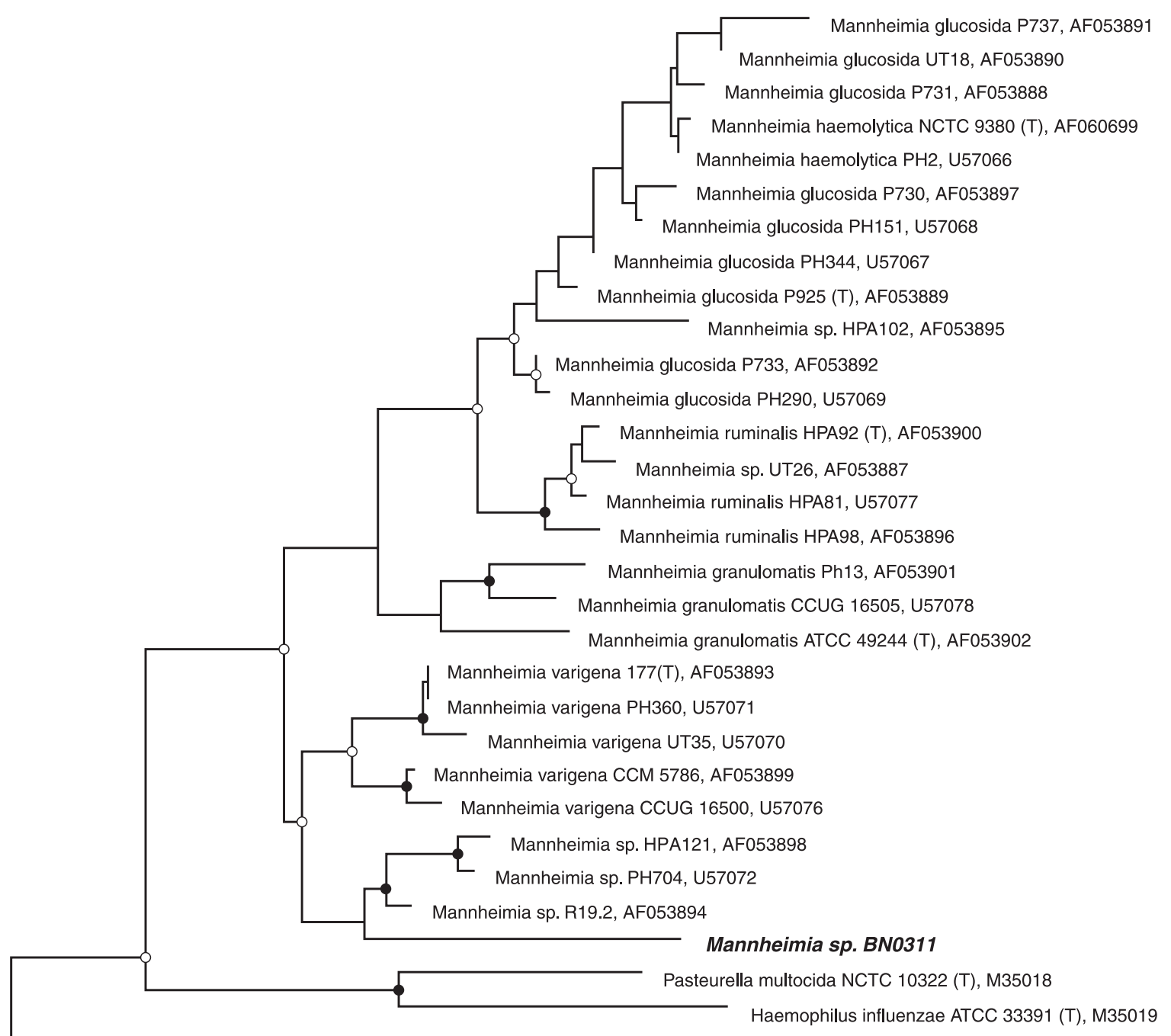

Actinobacillus lignieresii NCTC 4189 (T), M75068

Figure 2. Phylogenetic position of BNO311 in relation to genus Mannheimia and selected type strains representing other genera of the family Pasteurellaceae. Branch points supported (bootstrap values, $>75 \%$ ) by all inference methods used are indicated by solid circles, and those supported by most inference methods are indicated by open circles. Branch points without circles were not resolved (bootstrap values, $<75 \%$ ).

organisms, it should be possible to develop a clearer picture of the role of these organisms in bovine respiratory disease.

0 verall, the phenotypic and genotypic results indicate that the Australian isolates appear to represent a new taxon within the genus Mannheimia. However, further DNA:DNA hybridisation studies are necessary to support the formal proposal of a new species. H ence, for the moment, we suggest the use of Bisgaard Taxon 39 of $M$ annheimia rRN A cluster $V$ to refer to these organisms.

\section{Acknowledgments}

The assistance of $D r$ Peter Young in allowing access to the cattle from which these isolates were obtained is gratefully acknowledged.

\section{References}

1. Mutters R, Ihm P, Pohl S, Frederiksen W, Mannheim W. Reclassification of the genus Pasteurella Trevisan 1887 on the basis of deoxyribonucliec acid homology, with proposals for the new species Pasteurella dagmatis, Pasteurella canis, Pasteurella stomatis, Pasteurella anatis, and Pasteurella langaa. Int J Syst Bacteriol 1985;35:309-322.

2. Frank GH. Pasteurellosis of cattle. In: Adlam C, Rutter JM, editors. Pasteurella and Pasteurellosis. Academic Press, London, 1989:197-222.

3. Smith GR. Isolation of two types of Pasteurella haemolytica from sheep. Nature (Lond) 1959;183:1132-1133.

4. Smith GR. The characteristics of two types of Pasteurella haemolytica associated with different pathological conditions in sheep. I Path Bact 1961;81:431-440.

5. Frederiksen W. Pasteurella taxonomy and nomenclature. Contrib Microbiol Immunol 1973;2:170-176.

6. Biberstein EL, Francis CK. Nucleic acid homologies between the A and T types of Pasteurella haemolytica. J Med Microbiol 1968;1:105-108.

7.Pohl S Reklassifizierung der Gattungen Actinobacillus Brumpt 1910, Haemophilus Winslow et al. 1917 und Pasteurella Trevisan 1887 anhand phänotypischer und molekularer Daten, insbesondere der DNSVerwandtschaften bei DNS:DNS - hybridisierung in vitro und Vorschlag einer neuen Familie, Pasteurelllaceae [PhD thesis]. Philipps-Universität, Marburg, Germany, 1979.

8. Mannheim W. Taxonomy of the family Pasteurellaceae Pohl 1981 as revealed by DNA:DNA hybridization. INSERM 1983;114:211-226.

9. Sneath PH, Stevens M. Actinobacillus rossii sp. nov., Actinobacillus seminis 
sp. nov., nom. rev., Pasteurella bettii sp. nov., Pasteurella lymphangitidis sp. nov., Pasteurella mairi sp. nov., and Pasteurella trehalosi sp. nov. Int J Syst Bacteriol 1990;40:148-153.

10. Angen $\varnothing$, Aalbaek B, Falsen E, Olsen JE, Bisgaard M. Relationships among strains classified with the ruminant Pasteurella haemolytica-complex using quantitative evaluation of phenotypic data. Zentralbl Bakteriol 1997;285:459479.

11. Angen $\varnothing$, Olsen JE, Bisgaard M. Further studies of the relationships among strains classified as taxon 15, taxon 18, taxon 20, (Pasteurella) granulomatis or the (Pasteurella) haemolytica-complex in ruminants using quantitative evaluation of phenotypic data. Zentralbl Bakteriol 1997;286:317-332.

12. Angen $\varnothing$, Caugant DA, Olsen JE, Bisgaard M. Genotypic relationships among strains classified under the (Pasteurella) haemolytica-complex as indicated by ribotyping and multilocus enzyme electrophoresis. Zentralb/ Bakteriol 1997;286:333-354.

13. Angen $\varnothing$, Mutters R, Caugant DA, Olsen JE, Bisgaard M. Taxonomic relationships of the [Pasteurella] haemolytica complex as evaluated by DNADNA hybridizations and 16S rRNA sequencing with the proposal of Mannheimia haemolytica gen. nov., comb. nov., Mannheimia granulomatis comb. nov., Mannheimia glucosida sp. nov., Mannheimia ruminalis sp. nov. and Mannheimia varigena sp. nov. Int J Syst Bacteriol 1999;49:67-86.

14. Angen $\varnothing$, Quirie M, Donachie W, Bisgaard M. Investigations on the species specificity of Mannheimia (Pasteurella) haemolytica serotyping. Vet Microbiol 1999;65:283-290.

15. Bisgaard M, Houghton SB, Mutters R, Stenzel A. Reclassification of German, British and Dutch isolates of so-called Pasteurella multocida obtained from pneumonic calf lungs. Vet Microbiol 1991;26:115-124.

16. Sambrook J, Fritsch EF, Maniatis T. Molecular Cloning: A Laboratory Manual. Cold Spring Harbour Laboratory Press, Cold Spring Harbor, NY, 1989:2000.

17. Lane DJ. 16S/23S rRNA sequencing. In: Stackebrandt E, Goodfellow M, editors. Nucleic acid techniques in bacterial systematics. John Wiley \& Sons, Chichester, 1991;115-175.

18. Dorsch M, Stackebrandt E. Some modifications in the procedure of direct sequencing of direct PCR amplified 16S rDNA. J Microbiol Methods 1992;16:271-279.

19. Strunk O, Gross O, Reichel B, May M, Hermann S, Stuckman N, Nonhoff B, Lenke M, Ginhart A, Vilbig A, Ludwig T, Bode A, Schleifer K-H, Ludwig W (1999): ARB: a software environment for sequence analysis. http://www.mikro.biologie.tu-meunchen.de. Department of Microbiology Technicshe Universität München, Munich, Germany.

20. Olsen GJ, Matsuda H, Hagstrom R, Overbeek R. fastDNAml: a tool for construction of phylogenetic trees of DNA sequences using maximum likelihood. Comput Appl Biosci 1994;10:41-48.

21. Dalevi D, Hugenholtz P, Blackall LL. A multiple-outgroup approach to resolving divison-level phylogenetic relationships using 16S rRNA data. Int $J$ Syst Evol Microbiol 2001;51:385-391.

22. De Ley J, Cattoir H, Reynaerts A. The quantitative measurement of DNA hybridization from renaturation rates. Eur J Biochem 1970;12:133-142.

23. Gillis M, De Ley J, De Cleene M. The determination of molecular weight of bacterial genome DNA from renaturation rates. Eur J Biochem 1970;12:143153.

24. Grimont F, Grimont PAD. Ribosomal ribonucleic acid gene restriction patterns as potential taxonomic tools. Annales Inst Pasteur/Microbiol 1986;137:165-175.

25. Swofford DL, Olsen GJ. Phylogeny reconstruction. In: Hillis DM, Moritz C, editors. Molecular Systematics. Sinauer Associates Inc, Sunderland, 1990:411501.

26. Blackall PJ, Christensen JP, Bisgaard M. Diversity among isolates of Actinobacillus equuli as revealed by ribotyping. Aust Vet $J$ 1998;76:423-425.

27. Blackall PJ, Fegan N, Chew GTI, Hampson DJ. Population structure and diversity of avian isolates of Pasteurella multocida from Australia. Microbiology 1998;144:279-289.

28. Ochman H, Whittam TS, Caugant DA, Selander RK. Enzyme polymorphism and genetic population structure in Escherichia coli and Shigella. J Gen Microbiol 1983;129:2715-2726.

29. Selander RK, McKinney RM, Whittam TS et al Genetic structure of populations of Legionella pneumophila. J Bacteriol 1985;163:1021-1037.

30. Selander RK, Beltran P, Smith NH. Evolutionary genetics of Salmonella. In: Selander RK, Clark AG, Whitam TS, editors. Evolution at the molecular level. Sinauer Associates, Sunderland, 1991:25-57.

31. Gilmour MN, Whittam TS, Kilian M, Selander RK. Genetic relationship among oral streptococci. J Bacteriol 1987:169:5247-5257.

(Accepted for publication 2 February 2001)

\section{BOOK REVIEW}

Social Behaviour in Farm Animals. Edited by Keeling LJ and Gonyou HW, CABI Publishing, Wallingford, 2001,432 pages. Price US\$110.00. ISBN 0851993974.

his book is a welcome addition to the excellent series of animal behaviour and welfare texts produced by CABI over the last 10 years. The book's objective is to describe the social behaviour of farm animals and how this is affected in modern management systems.

The book is divided into three sections; Concepts in Social Behaviour (4 chapters), The Social Behaviour of Domestic Animals (6 chapters) and Contemporary Topics in Social Behaviour (4 chapters). The first section deals with the evolution of social behaviour including domestication and has a chapter on parental behaviour. The second section is descriptive with a chapter on the social behaviour of each of the common farm species, cattle, pigs, domestic birds, sheep, horses, and fish. The final section looks at the role of humans in the life of farm animals, the effects of breaking social bonds, animal personalities and social cognition.

Each chapter is written by one or more recognised authorities in the subject area. It is pleasing to note that the chapter on sheep was written by Andrew Fisher and Lindsay Matthews from New Zealand. The editors preface each chapter with a brief comment on its significance. Each chapter is a review of the subject and many identify areas still to be investigated.

The social behaviour of water buffalo, goats, camels, deer and dogs are not described. The species covered are those that have had the most research carried out on them over the last half century. Much of that research was stimulated by concern about animal welfare in intensive farm management systems.

This is an excellent book. It is easy to read, thorough and interesting. If you are interested in farm animals and in how they live you will enjoy this book. The evolutionary perspective is unusual in animal science textbooks because of concerns about its relevance to domesticated animals. This is recognised by the authors but they consider it to be a valuable background for the understanding of social behaviour.

The chapters on the social behaviour of farm animals, poultry and fish are all of a high standard and should be of value to veterinarians with an interest in any of these species. Those with an interest in a particular species will be familiar with much of the material but reading an up-to-date review is worthwhile and may boost one's ego a little.

The section on humans and farm animals does not feature Paul Hemsworth and this is unusual given his expertise in the area. This section contains an interesting discussion on humans in the world of animals by Jeffrey Rushen and others.

This is a book to read for pleasure and information. In a world where veterinarians are expected to know not only about health and productivity but also about 'welfare' this book is very useful. It is of particular interest to everyone interested in farm animal behaviour and welfare. It is recommended Christmas reading for those who cannot be bothered to read traditional holiday blockbusters.

\section{KJ Stafford}

